\title{
APAKAH AUDIT JUDGMENT DIPENGARUHI OLEH UKURAN PERUSAHAAN, TEKANAN KETAATAN, DAN PENGETAHUAN AUDITOR?
}

\author{
Winda Apriliastuty ${ }^{1}$, Supri Wahyudi Utomo², dan Nur Wahyuning Sulistyowati \\ Fakultas Keguruan dan Ilmu Pendidikan, Program Studi Pendidikan Akuntansi, \\ Universitas PGRI Madiun ${ }^{1,2,3}$ \\ E-mail: windaapriliastuty24@gmail.com
}

\begin{abstract}
This study aims to examine the effect of company size, compliance pressure, and auditor knowledge on audit judgment. This type of research is quantitative research. The sampling technique was purposive sampling with a sample of 18 companies 56 financial statements. The data analysis technique used in this study is a statistical regression using the IBM SPSS Statistics version 22 program. The results show that: obedience pressure and auditr knowledge influence audit judgment because obedience pressure is influenced by the client and the senior auditor and the level of knowledge influence judgment given the auditor. The size of the company does not affect audit judgment because a small amount of assets does not affect the evaluation results of the auditor's judgment.
\end{abstract}

Keywords : Company Size; Pressure; Knowledge; Audit.

\section{Pendahuluan}

Barang konsumsi makan dan minum (Food and Beverage) adalah perusahaan sektor industri barang mentah yang mengolah menjadi barang jadi. Pada tahun 2016 sektor makanan dan minuman mengalami penurunan dalam jumlah pendapatan, namun data Kementrian Perindustrian telah mencatat bahwa pada kuartal III 2017 sektor makan dan minum telah memberikan kontribusi sebesar 34,5\% produk Domestik Bruto. Faktor yang medukung pertumbuhan sektor makan dan minum adalah adanya kebijakan mengenai deregulasi yang mumudahkan perusahaan untuk mendapatkan bahan baku, sehingga harapan pada tahun 2018 sektor makan dan minuman dapat meningkat 10 persen (Kencana R, 2018). Dengan adanya berita tersebut maka ukuran perusahaan dalam sektor makanan dan minuman dapat mengalami kenaikan pada total aset. Ukuran perusahaan adalah suatu nilai yang ada pada perusahaan yang diukur dari total harta yang dimiliki perusahaan, jumlah modal, pendapatan dan juga banyak karyawan sehingga dapat digolongkan sebagai perusahaan besar (Prasetyorini, 2013). Entitas yang besar menggunakan modal untuk membelanjakan aktiva. Sedangkan perusahaan akan lebih berhati - hati membelanjakan modalnya jika ukuran perusahaannya kecil (Kusumo \& Ari, 2016). Perusahaan melakukan kegiatan produksi supaya menghasilkan barang atau jasa yang dapat dijual kepada konsumen dan perusahaan mendapatkan keuntungan (Patricia, 2018). Perusahaan dituntut memberikan bukti berupa catatan perusahaan yang sudah diperiksa oleh audit independen. Namun pada kenyataannya banyak kegagalan audit terjadi hal ini dapat memunculkan krisis kepercayaan terhadap masyarakat terkait dengan profesi akuntan (Ainia \& Prayudiawan, 2011).

Dalam melakukan pekerjaan auditor mendapatkan tekanan ketaatan yang melakukan penyimpangan standar akuntansi karena adanya paksaan dari orang lain. Pemeriksa keuangan yang masih junior biasanya mendapat tekanan ketaatan dari auditor senior, dilain pihak bisanya klien akan meminta auditor untuk melakukan penyimpangan standar yang berlaku supaya laporan keuangan yang disajikan dapat menyajikan laporan keuangansecara wajar 
(Ariyantini, Sujana, Ari, \& Darmawan, 2014). Saat ini Kantor Akuntan Publik berlomba lomba untuk meningkatkan jumlah klien supaya KAP dianggap baik dan profesional (Sofiani \& Tjondro, 2014). Sebelum melakukan pekerjaan auditor mempunyai tahapan - tahapan dalam bekerja, yaitu: klien menghubungi calon auditor yang ditunjuk untuk mengevaluasi dan mencocokkan data perusahaan, kemudian antara pihak perusahaan dan calon audit membuat perjanjian secara tertulis maupun bertemu secara langsung untuk kesepakatan bekerja, lalu auditor menyiapkan surat perjanjian penawaran dalam bentuk proposal untuk melakukan tugasnya dalam pemeriksaan laporan keuangan yang ada dalam perusahaan, yang terakhir auditor menyampaikan hasil analisis dan evaluasi bagi perusahaan mengenai kelemahan yang harus dirubah atau diperbaiki supaya pengendalian intern perusahaan tetap terjaga dengan baik (Sukrisno, 2016).

Pengetahuan yang luas memudahkan auditor dalam menjalankan pekerjaan, karena banyaknya pengetahuan dan pengalaman akan lebih mudah untuk mendeteksi salah saji laporan keuangan (Trisnani, 2010). Hasil proses pemeriksa laporan keuangan yaitu penyampaian opini yang dilakukan pemeriksa laporan keuangan untuk perusahaan mengenai kewajaran penyampaian catatan perusahaan yang akan disampaikan kepada pihak yang berkepentingan. Audit judgment merupakan pertimbangan yang dikeluarkan auditor untuk menyampaikan opini laporan keuangan perusahaan yang dapat dipertanggungjawabkan karena adanya bukti - bukti pendukung. Kualitas dari judgment sangat dipertimbangkan untuk mengukur kinerja auditor dalam menjalankan tugasnya, karena auditor harus bersikap independen agar judgment yang dikeluarkan tidak dapat dipengaruhi dan mendapat tekanan ketaatan dari pihak lain (Refdi1, Kirmizi, \& Restu, 2010). Tingkat pengetahuan auditor juga mempengaruhi keefektifan kerja auditor. Dengan tingkat pengetahuan yang tinggi maka pemeriksa catatan perusahaan lebih tepat untuk memberikan sebuah judgment pada perusahaan yang diperiksa laporan keuangannya. Pengetahuan tidak hanya didapatkan dari sekolahan maupun buku teori, namun juga dari pengalaman - pengalaman yang diperoleh auditor dari pekerjaan yang sudah digelutinya. Banyaknya pengalaman auditor akan memudahkan pekerjaan sehingga pekerjaan yang dilakukan akan lebih menghemat waktu dan pekerjaan akan terselesaikan dengan memberikan judgment yang tepat pada perusaan (Fitriani \& Daljono, 2012).

Tekanan ketaatan berpengaruh terhadap audit judgment pada hasil akhir penelitian dari (Drupadi1 \& Sudana, 2015). Adanya tekanan ketaatan akan mempengaruhi pemberian judgment yang diberikan auditor untuk perusahaan sehingga tekanan ketaatan baik dari klien maupun dari atasan akan berpengaruh terhadap audit judgment (Tampubolon, 2018). Ukuran perusahaan berpengaruh terhadap nilai perusahaan pada hasil penelitian yang dikemukakan (Arisadi, Djumahir, \& Atim, 2011). Pengetahuan auditor berpengaruh signifikan terhadap audit judgment penelitian dari (Putri, 2015). Ditinjau dari pembahasan di atas penelitian ini terjadi pembaharuan karena perbedaan pada lokasi penelitian, waktu penelitian, dan variabel yang berbeda dari penelitian - penelitian yang sebelumnya, yaitu mengenai audit judgment yang berpengaruh atau tidaknya ukuran perusahaan, tekanan ketaatan dan pengetahuan auditor.

Tujuan dalam penelitian ini adalah untuk mendiskripsikan pengaruh antara ukuran perushaan, tekanan ketaatan, dan pengetahuan auditor terhadap audit judgmnet pada perusahaan food and beverage yang terdaftar di BEI periode 2016 - 2018. Setelah dilakukannya penelitian, maka ada beberapa manfaat yang dapat memberikan suatu informasi. Kegunaan dari penelitian ini yakni: 1) mengembangkan ilmu pengetahuan dalam bidang manajemen keuangan maupun menambah wawasan mengenai laporan keuangan, sehingga dapat dijadikan bahan pertimbangan untuk mengetahui pengaruh dari audit judgmet.; 2) Bagi perusahaan penelitian ini dapat menjadi bahan pertimbangan karena bisa menjadi masukan yang positif agar mencari auditor yang kompeten dalam bidangnya 
sehingga dapat menghindari kesalahan pemberian judgment yang dilakukan oleh auditor, dan menghindari kesalahan yang dapat merugikan perusahaan; 3) Bagi investor dapat mengetahui dan memberikan manfaat tambahan informasi untuk mengetahui kesehatan perusahaan yang sudah diaudit oleh TIM auditor sehingga hasil judgment sesuai dengan kondisi yang ada di perusahaan; 4) Untuk penulis dapat bermanfaat menambah informasi dan pembelajaran yang baru dalam menganalisis laporan keuangan khususnya mengenai audit judgment di sektor food and beverage periode 2016 - 2018; 5) Bagi pihak lain untuk mengetahui kondisi perusahaan, tambahan informasi pada perusahaan, maupun untuk referensi bagi peneliti berikutnya yang ingin mengetahui lebih luas tentang audit judgment.

\section{Tinjauan Literatur dan Pengembangan Hipotesis}

Ukuran Perusahaan. Banyak karyawan, total harta yang dimiliki perushaaan, jumlah modal perusahaan, nilai saham perusahaan, dan jumlah pendapatan yang dapat dihitung merupakan suatu ukuran perusahaan (Setiawan, 2014). Besar perusahaan yang diukur dari jumlahnya harta yang dimiliki perusahaan untuk melakukan kegiatan produksi merupakan bagian dari ukuran perusahaan. Perusahaan melakukan kegiatan prooduksi supaya menghasilkan yang dapat dijual kepada konsumen dan perusahaan mendapatkan keuntungan(Yangs, 2011).

Dari pendapat di atas dapat dikatakan bahwa besar kecilnya ukuran perusahaan yang dilihat dari catatan pembukuan perusahaan yang berfokus pada harta perusahaan. Harta yang dimiliki perusahaan akan berpengaruh pada proses produksi, karena dengan harta yang banyak akan memungkinkan untuk dibelanjakan oleh manajer sehingga proses produksi dapat berjalan sesuai yang diharapkan.

Dalam UU No. 20 Tahun 2008 menyatakan bahwa kriteria ukuran perusahaan digolongkan menjadi 4 bagaian, yaitu:

1. Usaha yang memiliki kekayaan bersih sebesar Rp 50.000.000 sampai dengan Rp 300.000.000 di golongkan menjadi usaha mikro, namun bangunan dan tanah tidak masuk dalam hitungan perolehan kekayaan bersih. Usaha mikro merupakan badan usaha perorangan dengan usaha produktif.

2. Usaha yang memiliki kekayaan bersih sebesar Rp 50.000.000 sampai dengan Rp 500.000.000 di golongkan menjadi usaha kecil namun bangunan dan tanah tidka masuk dalam hitungan perolehan kekayaan bersih. Usaha kecil merupakan badan usaha perorangan yang berdiri sendiri. Total pendaatan tahunan setia tahun sebesar Rp 300.000.000 sampai dengan Rp 2.500.000.000.

3. Usaha yang mempuyai total pendaatan sebesar $\mathrm{Rp} 2.500 .000 .000$ sampai dengan $\mathrm{Rp}$ 50.000.000.000 yang memiliki aset sebesar Rp 500.000.000 sampai dengan Rp 10.000.000.000 digolongkan menjadi usaha menengah. Usaha menengah merupakan badan usaha yang didirikan sendiri yang bukan merupakan golongan usaha kecil.

4. Usaha besar merupakan usaha yang dimiliki oleh negara attau nasional atau swasta yang memiliki pendapatan dan jumlah aset leih dari yang dimiliki usaha menengah. Usaha besar bisanya juga hasil patungan dari usaha asing yang melakukan kegiatan usaha.

Indikator ukuran perusahaan yaitu kondisi yang dapat menunjukkan jumlah harta yang dimiliki perusahaan. Jumlah aktiva yang banyak dapat menggunakan modal pinjaman untuk membelanjakan aktiva dibandingkan menggunakan jumlah harta yang sedikit dimiliki perusahaan. Dapat disimpulkan bahwa ukuran perusahaan ditentukan dari jumlah aktiva. Alat 
ukur ukuran perusahaan adalah Logaritma dari jumlah aktiva. Logaritma berguna untuk meudahkan perhitungan yang sangat besar dibandingkan dengan variabel keuangan yang lain (Nora, 2016).

\section{Ukuran perusahaan $($ size $)=\operatorname{Ln}($ Total aktiva $)$}

Tekanan Ketaatan. Tekanan ketaatan merupakan penyimpangan yang dilakukan auditor untuk tidak mentaati peraturan kode etik yang biasanya diterima auditor dari pihak atasan maupun dari pihak klien. Tekanan ketaan akan mempengaruhi pemberian judgment untuk memberikan evaluasi bagi perusahaan (Putri, 2015).

Perintah atasan maupun perintah klien merupakan hal yang bisanya diterima auditor dalam melakukan pekerjaan sehingga auditor mendapatkan dilema etika berupa tekanan ketaatan yang dapat menyimpang standar yang berlaku dalam akuntansi. Tekanan ketaatan juga dapat mempengaruhi pemberian opini audit dalam kewajaran laporan keuangan. Tekanan ketaatan diukur dalam pergantian auditor selama beberapa lama auditor bekerja pada perusahaan tersebut.

Indikator tekanan ketaatan digambarkan apabila seorang Auditor mengalami dilema etika ketika melakukan pekerjaan. Dilema etika tersebut terjadi ketika auditor mendapatkan perintan atasan maupun klien untuk melakukan penyimpangan standar profesi dan sikap independensi dalam melakukan pekerjaan. Dilema etika dapat dilgolongkan menjadi dua, yaitu (Angga, 2015):

1. Tekanan Ketaatan dari pihak Perusahaan (Klien)

Tekanan ini biasanya diterima auditor dari pihak perusahaan yang akan diaudit. Audior mendapatkan tekanan ketaatan untuk melakukan penyimpangan dalam proses pengecekan catatan pembukanan perusahaan sehingga catatan pembukuan yang dipamerkan kepada pembaca mendapatkan opini wajar tanpa pengecualian sehingga banyak investor maupun pihak yang berkepentingan akan tertarik untuk bergabung dalam perusahaan. Jika auditor melakukan penyimpangan yang diperintahkan oleh klien maka auditor telah melanggar kode etik profesi dan indepenensi. Namun jika auditor tidak melakukan perintah klien maka kemungkinan besar jasa auditor tidak akan digunakan lagi pada tahun berikutnya.

2. Tekanan Ketaatan dari Auditor Senior (Atasan)

Tekanan dari pemeriksa laporan keuangan yang senior merupakan tekanan ketaatan yang diterima dari auditor junior terhadap auditor senior. Kekuasaan yang diterima dari auditor senior akan mempengaruhi perilaku auditor junior sehingga akan mendapatkan otoritas kerja yang lebih.

Pengetahuan Auditor. Pengetahuan auditor yaitu pemahaman tugas yang akan dilakukan oleh auditor secara teoritis maupun konseptual. Pengetahuan audit merupakan kemampuan auditor melakukan pemeriksaan laporan keuangan. Pengetahuan dapat diperoleh dari pengalaman langsung maupun pengalaman tidak langsung (Putri, 2015).

Pengetahuan auditor yang luas akan memudahkan kinerja audit untuk menyelesaikan pekerjaan audit secara lebih mudah dan memiliki pandang yang luas mengenai banyak hal. Pengetahuan yang dimiliki auditor merupakan acuan untuk mengambil sebuah keputusan (Fitriani \& Daljono, 2012). Kesimpulan dari pendapat di atas yaitu pengetahan merupakan hal pokok yang harus dimiliki auditor untuk mumudahkan pekerjaan dan untuk mengambil 
sebuah keputusan. Pengetahuan tidak hanya diperoleh dari pendidikan namun juga banyaknya pengalaman yang diperoleh auditor.

Ilmu pengetahuan mempunyai ciri-ciri untuk menyelesaiakan persoalan yang dihadapi karena pemecahan suatu masalah didasarkan bagaimana cara menyelesaiakan persoalan. Ciriciri pengetahuan yaitu (Ihsan, 2010:113):

1. Pengetahuan dapat diperoleh berdasarkan hasil percobaan yang dilakukan sendiri (empiris).

2. Dengan pengumpulan sumber-sumber data yang dikumpulkan dihubungkan dengan cara terstruktur (sistematis)

3. Pengetahuan yang bebas yang dimilkiki oleh diri sendiri sesuai dengan kesenganan pribadi (objektif)

4. Dapat membeda-bedakan beberapa hal untuk menyusun suatu jawaban dalam memecahkan persoalan sehingga hasilnya terperinci dalam beberapa bagian (analistis)

5. Orang lain dapat memberikan kebenaran dari hasil yang disampiakan oleh ilmuwan (verifikatif).

Pengetahuan auditor dapat diukur dari tingkat pendidikan auditor maupun pengalaman yang diperoleh auditor. Banyaknya pengalaman yang diperoleh auditor akan semakin mempermudah kinerja yang dilakukan untuk menganalisis hasil akhir dari catatan perusahaan berupa laporan keuangan entitas yang dicatat sesuai dengan pedoman akuntansi yang berlaku. Ada tiga jenis pengetahuan auditor yang berkaitan dengan kinerja audit, yaitu (Putri, 2015):

1. Tanggunjawab auditor dalam penyampaian laporan dan cara menyelesaiakan pekerjaan auditor

2. Auditor mengetahui semua jenis surat-surat yang ada dalam perusahaan dan mengetahui alur dari surat diperoleh

3. Pengetahuan tentang terjadinya salah saji maupun kecurangan yang dapat merugikan pihak-pihak yang berkepentingan maupun kemampuan auditor menguasai sisi psikologi.

Audit Judgement. Audit judgment adalah suatu pertimbangan auditor untuk menyampaikan informasi mengenai catatan perusahaan dengan standar akuntansi yang berlaku untuk membuat penilaian atas kewajaran laporan keuangan. Dalam pembuatan penilaian auditor mempunyai tangguungjawab yang tinggi karena penilaian akan dimintai keterangan yang mendukung (Ariyantini, 2014).

Audit judgment merupakan proses pengambilan keputusan untuk memberikan opini, evaluasi dan sikap karena judgment berkaitan dengan sudut pandang individu auditor. Judgment sangat berkaitan erat dengan sikap auditor yang harus idependen, kerana hal tersebut akan mempengaruhi kualitas hasil kinerja audit dalam memyampaikan sebuah pendapat wajar tanpa pengecualian pada hasil laporan keuangan perusahaaan (Kusumawardhani, 2014).

Kesimpulan pendapat di atas adalah audit judgment merupakan pertimbangan untuk memberikan evaluasi hasil kinerja audit yang didukung dengan adanya bukti yang otentik 
dari auditor. Auditor dituntut untuk bersikap independen supaya hasil dari judgment tidak dapat dipengaruhi oleh pihak klien maupun atasan dari auditor senior, karena judgment akan mempengaruhi hasil dari opini audit pada hasil akhir kinerja auditor.

Opini Audit. Opini audit merupakan pendapat auditor mengenai kesusuaian laporan keungan dengan standar akuntansi yang berlaku umum dari berbagai elemen mulai dari profil perusahaan, struktur organisasi perusahaan, maupun tindakan yang menyimpang sehingga dapat merugikan pembaca catatan pembukuan perusahaan. Baik buruknya perusahaan biasnaya dilihat dari pemberian opini audit (Hanif, 2018).

Opini audit merupakan salah satu pernyataan yang disampikan auditor mengenai halhal hasil evaluasi data dari pihak perusahaan yang diperiksa auditor mengenai keajaran laporan keuangan yang dicatat perusahaan susuai dengan prinsip akuntansi yang diperlakukan di Indonesia. Auditor dapat memberikan opininya yang akan disampaikan, ada 5 pendapat yang akan disampikan oleh auditor terhadap laporan keuangan, yaitu: 1) wajar tanpa pengecualian; 2) wajar dengan kalimat penjabaran; 3) wajar menggunakan pengecualian; 4) tidak wajar; 5) tidak memberikan pendapat.

1. Wajar tanpa pengecualian

Catatan pembukuan yang bebas dari salah baik material maupun non meterial yang bersifat wajar tanpa ada penyimpangan akan mendapatkan opini wajar tanpa pengecualian dari auditor (Messier, 2014:22). Prinsip-prinsip akuntansi yang berlaku umum akan mempengaruhi hasil dari laporan keuangan yang wajar maka akan mendapatkan opini wajar tanpa pengecualia dari auditor (Rendal, 2014:55). Dari pendapat di atas maka dapat disimpulkan bahwa opini wajar tanpa pengecualian merupakan pendapat yang diberikan auditor pada perusahaan yang menyajikan laporan keuangan dengan yang sesungguhnya tanpa adanya kecurangan dengan prinsip akuntansi yang berlaku secara umum, sehingga pembaca lapooran kuangan tidak akan merasa dirugikan.

2. Pendapat wajar tanpa pengecualian dengan bahasa penjelas

Bahasa penjelas yang diberikan auditor biasanya karena adanya kondisi tertentu sehingga aditor harus memberikan penjelasan terhadap pendapat yang disampikan (Messier, 2014:203). Laporan keuangan sudah disajikan secara wajar tanpa adanya kecurangan, namum auditor perlu menambahkan beberapa pejelasan menegenai laporan keuangan yang disajikan oleh perusahaan (Rendal, 2014:61). Kesimpulan dari pendapat di atas adalah opini wajar tanpa pengecualian dengan bahasa penjelas yaitu laporan keuangan yang disampaikan perusahaan memenuhi syarat dan tidak ada kesalahaan materiil dalam laporan, namum auditor menberikan pendapat tambahan mengenai laporan audit.

3. Pendapat wajar dengan pengecualian

Keterbatasan dalam ruang lingup audit akan menyebabkan auditor bekerja tidak secara maksimal dan dapat menyebabkan penyimpangan terhadap Prinsip Akuntansi Berterima Umum (PABU) (Messier, 2014:192). Wajar tanpa pengecualian terjadi karena terbatasnya ruang lingkup dalam menganalisis laporan keuangan klien, sehingga data-data perusahaan tidak disajikan secara lengkap (Rendal, 2014:67). Kesimpulan dari pendapat di atas adalah laporan keuangan yang di audit disajaikan secara wajar tanpa kesalahan meteriil namun ada beberapa hal yang dikeculaikan sehingga laporan tersebut mendapatkan opini wajar dengan pengecualian

4. Pendapat tidak wajar 
Pendapat tidak wajar disampikan auditor terjadi karena adanya kelemanahan yang meterial terhadap laporan keuangan yang disampikan oleh auditor sehingga dapat merugikan pihak-pihak yang berkepentingan (Messier, 2014:257). Laporan keuangan tidak menyampaikan secara wajar sehingga prinsip akuntansi yang diterima umum bertolak belakang dengan laporan yang ada dalam perusahaan dan menyebabkan kesalahan laporan keuangan yang meteriil (Rendal, 2014:67). Pendapat di atas dapat disimpulkan bahwa pendapat tidak wajar menyatakan bahwa laporan posisi keuangan hasil usaha, tidak disajikan secara wajar sehingga dapat merugikan pihak yang berkepnetingan dalam laporan keuangan.

5. Tidak memberikan pendapat

Tidak memberikan pendapat terjadi karena auditor tidak yakin terhadap diri sendiri mengenai kewajaran laporan keuangan yang telah diaudit (Rendal, 2014:67). Bukti yang diberkan oleh klien kurang dan ruang lingkup terbatas sehingga auditor tidak dapat memberikan pendapat mengenai laporan keuangan perusahaan (Messier, 2014:192). Dapat disimpulkan bahwa audit tidak dapat memberikan pendapat karena terbatasnya ruang lingkup dan bukti-bukti yang diterima auditor kurang sehingga tidak dapat menyampiakan pendapatnya mengenawai kewajaran posisi keuangan perusahaan. Indikator dari audit judgment ini merupakan hasil opini auditor, jika perusahaan mendapatkan poin wajar tanpa pengecalian diberi nilai 4; wajar dengan bahasa penjelas skor 3; wajar dengan pengecualian skor 2; tidak wajar skor 1 ; tidak memberikan opini 0.

Tahapan-tahapan Audit. Dalam menjalankan tugasnya auditor mempunyai alur kerja yang terstruktur sesuai dengan prosedur yang ditetapkan. Langkah-langkah yang dilakukan audit adalah sebagai berikut (Sukirno Agus, 2011:9):

1) Klien menghubungi calon auditor yang ditunjuk untuk mengevaluasi dan mencocokkan data perusahaan.

2) Klien dan calon audit membuat perjanjian secara tertulis maupun bertemu secara langsung untuk kesepakatan bekerja.

a) alasan harus dilakukan audit apakah karena ada pihak-pihak yang berkepentingan dalam laporan audit, misalnya pihak bank/pemberi pinjaman, para investor, kantor perpajakan, maupun perusahaan itu sendiri.

b) Apakah KAP yang lain sudah ada yang pernah memeriksa laporan keuangan perusahaan.

c) Apa saja jenis usaha yang dijalankan klien dan bagaimana gambaran perusahaan tersebut.

d) Proses pencatatan akuntansi diakukan secara tulis tangan atau dengan bantuan komputer.

e) Apakah bukti-bukti transaksi dan dokumen tersimpan dan tertata rapi.

3) Auditor menyiapkan surat perjanjian penawaran dalam bentuk proposal untuk melakukan tugasnya dalam pemeriksaan laporan keuangan yang ada dalam perusahaan (perjanjian berisi atas tawaran jasa kerja yang akan dilakukan auditor, biaya gaji yang akan dikeluarkan oleh perusahaan, waktu untuk memulai dan menyelesaikan pekerjaan auditor.) Apabila semua perjanjian disetujui oleh pihak klien dan auditor maka akan ada surat penugasan dan surat perjanjian kerja.

4) Auditor melakukan pekerjaan di kantor klien, ketika auditor menyelesakan pekerjaannya maka auditor akan memunculkan laporan audit dan penemuan-penemuan dari hasil pemeriksaan laporan keuangan klien. Draft laporan audit akan diserakan kepada klien 
ketika sudah disetujui oleh klien, kemudian auditor akan menyerahkan hasil akhir laporan audit.

5) Terakhir auditor menyampaikan hasil analisis dan evaluasi bagi perusahaan mengenai kelemahan yang harus dirubah atau diperbaik supaya pengendalian intern perusahaan tetap terjaga dengan baik.

Hipotesis bisa juga disebutkan menjadi acuan atau jawaban yang sifatnya sementara yang diambil dari rumusan permasalahan yang ada. Hipotesis ini disarankan melihat dari teori-teori yang relevan sehingga dapat menduga jawaban sementara dilihat dari fakta-fakta maupun kolektif data (Sugiyono, 2015:64). Berdasar pada pemaparan latar belakang, rumusan permasalahan yang dibuat, dan kerangka berfikir, jadi hipotesis research kali ini ialah seperti penggambaran berikut:

H1: Size Perusahaan mempunyai pengaruh pada Audit Judgmnetdi perusahaan Food and Beverage BEI 2016- 2018

H2: Tekanan Ketaatan mempunyai pengaruh pada Audit Judgment diperusahaan Food and Beverage BEI 2016 - 2018

H3: Pengetahuan Auditor mempunyai pengaruh padaAudit Judgment di perusahaan Food and Beverage BEI 2016 - 2018

H4: Size Perusahaan, Tekanan Ketaatan, dan Pengetahuan Audior mempunyai pengaruh terhadap AuditJudgment di perusahaan Food and Beverage BEI 2016 - 2018

\section{Metode Penelitian}

Jenis penelitian ini penelitian kuantitatif. Penelitian memakai sumber data sekunder dalam bentuk laporan keuangan tahunan yang sudah teraudit oleh perusahaan dan yang sudah dipublikasikan oleh Bursa Efek Indonesia (BEI) periode 2016 - 2018. Keseluruhan populasi di penelitian ini ialah beberapa perusahaan yang tercantum pada Bursa Efek Indonesia terkhusus perusahaan food and beverage pada tahun 2016 - 2018 yang berjumlah 52 perusahaan. Sampel yang diambil pada penelitian kali ini yaitu jumlah populasi, namun yang dipergunakan sesuai dengan syarat - syarat yang diharapkan oleh peneliti, yang nantinya tidak semua populasi dipakai. Dalam penelitian kali ini menggunakan sampel berupa laporan keuangan tahunan perusahaan food and beverage pada tahun 2016 - 2018, dan menghasilkan sampel sejumlah 18 perusahaan dengan 54 laporan keuangan tahunan. Teknik pengambilan sampel ialah purposive sample. Purposive sample yaitu adanya kriteria yang sudah ditentukan dan dengan pertimbangan - pertimbangan tertentu. Tujuan adanya purposive sample karena terbatasnya masa penelitian, anggaran yang digunakan dalam penelitian terbatas dan tenaga yang tidak memungkinkan sehingga tidak dapat mengambil sample dalam jumlah besar dan tempat penelitian yang jauh. Teknik analisis data yang dipakai yakni analisis statistik deskriptif, uji kelayakan model, serta analisis regresi logistik untuk mengetahui hipotesis setiap variabel.

\section{Hasil Penelitian dan Pembahasan}

Statistik Deskriptif. Statistik deskriptif menunjukkan jumlah terendah, jumlah terbanyak, jumlah rata - rata, standar deviasi, skewness, dan kuortosis pada masing - masing variabel penelitian dengan jumlah data 56. 
Tabel 1. Statistik Deskriptif

\begin{tabular}{lllllll}
\hline & Min & Max & Mean & Std. Deviasi & Skewness & Kurtosis \\
\hline Ukuran Perusahaan (X1) & 21,04 & 29,98 & 25,773 & 2,94235 &,- 435 & $-1,389$ \\
Tekanan Ketaatan (X2) & 0 & 1 &, 89 &, 317 & $-2,546$ & 4,654 \\
Pengetahuan Auditor (X3) & 0 & 1 &, 52 &, 504 &,- 076 & $-2,072$ \\
Audit Judgment (Y) & 3 & 4 & 3,89 &, 317 & $-2,546$ & 4,654 \\
\hline
\end{tabular}

Sumber: Hasil Pengolahan Minitab

Berdasarkan tabel 1 yang disajikan di atas, dapat dijelaskan masing - masing variabel sebagai berikut: Jumlah rata - rata ukuran perusahaan adalah 25,773 dengan standar deviasi 2,94 yang berarti keragaman data rendah karena nilai mendekati 0. Nilai skewness sebesar 0,435 dan -1,389 menunjukkan bahwa data tidak berdistribusi normal karena nilai skewness dan kurtosis tidak sama dengan nol. Jumlah rata - rata tekanan ketaatan adalah 0,89 dengan standar deviasi 0,317 yang berarti keragaman data rendah karena nilai mendekati 0. Nilai skewness sebesar -2,546 dan 4,654 menunjukkan bahwa data tidak berdistribusi normal karena nilai skewness dan kurtosis tidak sama dengan nol. Jumlah rata - rata pengetahuan auditor adalah 0,52 dengan standar deviasi 0,504 yang berarti keragaman data rendah karena nilai mendekati 0 . Nilai skewness sebesar -0,076 dan -2,072 menunjukkan bahwa data tidak berdistribusi normal karena nilai skewness dan kurtosis tidak sama dengan nol. Jumlah rata rata audit judgment adalah 3,89 dengan standar deviasi 0,317 yang berarti keragaman data rendah karena nilai mendekati 0 . Nilai skewness sebesar -2,546 dan 4,654 menunjukkan bahwa data tidak berdistribusi normal karena nilai skewness dan kurtosis tidak sama dengan nol.

Uji Matrik Klasifikasi. Matrik klasifikasi menunjukkan kekuatan prediksi dari model regresi untuk memprediksi kemungkinan perusahaan opini wajar tanpa pengecualian maupun wajar dengan bahasa penjelas.

Tabel 2. Uji Matrik Klasifikasi

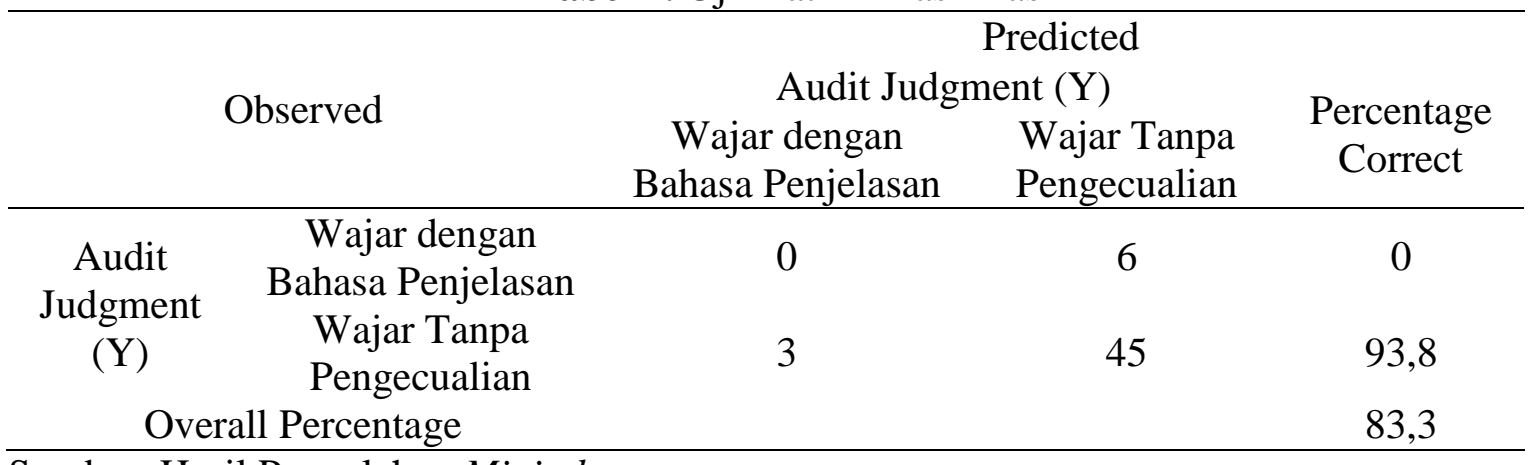

Sumber: Hasil Pengolahan Minitab.

Tabel 2 di atas dapat kekuatan prediksi dari model regresi untuk mengelompokkan kemungkinan perusahaan yang Wajar dengan Bahasa Penjelasan adalah sebesar 0\% dengan prediksi untuk perusahaan yang wajar dengan bahasa penjelasan diprediksi benar sebanyak 0 dan diprediksi salah sebanyak 6. Sedangkan perusahaan yang wajar tanpa pengecualian diprediksi benar sebanyak 3 dan diprediksi salah sebanyak 45 dengan persentase kebenaran sebesar 93,8\%. Secara keseluruhan, kemampuan model dalam memprediksi atau mengelompokkan perusahaan adalah sebesar $83,3 \%$.

Analisis Regresi Logistik. Uji ini untuk mengatahui pengaruh atau tidak berpengaruh Ukuran Perusahaan $\left(\mathrm{X}_{1}\right)$, Tekanan Ketaatan $\left(\mathrm{X}_{2}\right)$, Pengetahuan Auditor $\left(\mathrm{X}_{3}\right)$, terhadap Audit Judgment (Y) dilaksanakan uji hipotesis dengan berbantuan software Minitab 18.

Tabel 3. Uji Hipotesis Regresi Logistik 


\begin{tabular}{llll}
\hline & & B & $\operatorname{Exp}(\mathrm{B})$ \\
\cline { 2 - 4 } Step 1 & Ukuran Perusahaan (x1) &, 211 & 1,235 \\
& Tekanan Ketaatan (x2) & $-3,047$ &, 047 \\
Pengetahuan Auditor (x3) & $-1,346$ &, 026 \\
Constant & $-1,730$ &, 177 \\
\hline
\end{tabular}

Sumber: Hasil Pengolahan Minitab.

Berdasarkan Tabel 3 didapatkan persamaan model regresi sebagai berikut:

Audit Judgment $=0,177+1,235$ Ukuran Perusahaan+0,047 Tekanan Ketaatan $+0,260$ Pengetahuan Auditor.

Tidak seperti regresi linear sederhana, pada model regresi logistik, hubungan variabel independen dan variabel dependen diperhatikan dari nilai $\operatorname{Exp}(B)$. Jika nilai $\operatorname{Exp}(B)>1$ maka nilai tersebut diartikan sebagai wajar tanpa pengecualian, jika $\operatorname{Exp}(B)<1$ nilai tersebut diartikan sebagai wajar dengan bahasa penjelasan. Ukuran Perusahaan memiliki nilai Exp(B) sebesar 1,235 sehingga dapat dijelaskan bahwa setiap penambahan 1 satuan Ukuran Perusahaan kecenderungan perusahaan tersebut untuk wajar tanpa pengecualian meningkat 1,235 kali. Tekanan ketaatan memiliki nilai $\operatorname{Exp(B)~sebesar~0,047~yang~dapat~dijelaskan~}$ bahwa apabila mengalami kenaikan 1 satuan tekanan ketaatan, maka kecenderungan perusahaan tersebut wajar tanpa pengecualian meningkat sebesar 0,047 kali. Pengetahuan auditor, dengan nilai $\operatorname{Exp}(\mathrm{B})$ 0,026 sehingga setiap ada peningkatan pengetahuan auditor satu satuan, dapat kecenderungan entitas untuk wajar tanpa pengecualian akan naik sebesar 0,026 kali.

Uji Hipotesis Parsial. Uji parsial berguna untuk memberika penjelasan dari permsalahan dan dugaan sementara mengenai variabel yang dipengaruhi dan variabel yang dipengaruhi dilihat dari nilai signifikan yang ada pada hasil output menggunakan uji regresi logistik berbantuan software Minitab versi 18 dengan kaidah Uji hipotesis pada regresi logistik adalah dengan memperhatikan nilai signifikansi pada Wald di setiap variabel independen. Jika nilai signifikansi $<0,05$ maka variabel tersebut berpengaruh signifikan terhadap Audit Judgement.

Tabel 4. Uji Hipotesis Parsial

\begin{tabular}{cccc}
\hline & Wald df Sig. \\
\hline Step $1^{\text {a }}$ Ukuran Perusahaan (x1) & 1,051 & 1 &, 305 \\
Tekanan Ketaatan (x2) & 4,999 & 1 &, 025 \\
Pengetahuan Aditor (x3) & 3,244 & 1 &, 026 \\
Constant &, 116 & 1 &, 733 \\
\hline
\end{tabular}

Sumber: Hasil Pengolahan Minitab.

Tabel 4 memperlihatkan hasil signifikan yang dijadikan patokan dalam diterima atau ditolaknya hipotesis, yaitu sebagai berikut:

Ukuran perusahaan tidak berpengaruh signifikan terhadap Audit Judgement, berdasarkan uji hipotesis dengan menggunakan uji regresi logistik diperoleh temuan penelitian bahwa ukuran perusahaan tidak memiliki pengaruh terhadap audit judgment sehingga didapatkan kesimpulan bahwa variabel ukuran perusahaan tidak berpengaruh signifikan terhadap audit judgment. Audit judgment tidak berpengaruh terhadap ukuran perusahaan karena dalam melakukan tugas audit, tidak hanya dilihat dari total asetnya saja numun dari beberapa elemen yang dapat menunjukkan kesehatan perusahaan sehingga judgment yang diberikan auditor menyeluruh tidak hanya berfokus pada total asetnya saja. Perusahaan yang memiliki jumlah harta yang banyak tidak akan mempengaruhi judgment yang diberikan oleh perusahaan, namun auditor akan memberikan evaluasi dan memberikan 
saran yang membangun untuk mengembangkan bisnis yang dijalani oleh perushaan (Saragih, 2018).

Tekanan Ketaatan berpengaruh signifikan terhadap Audit Judgment, berdasarkan uji hipotesis dengan menggunakan uji regresi logistik diperoleh temuan tekanan ketaatan berpengaruh signifikan terhadap Audit Judgment pada perusahaan food and beverage tahun 2016-2018. Auditor akan mendapatkan tuntutan dari pihak klien untuk memberikan pernyataan wajar pada laporan keuangan sehingga dianggap perusahaan mengalami kemajuan yang pesat dalam bekerja lalu perusahaan dianggap baik, dan memberikan pandangan bagus bagi investror maupun pihak - pihak yang berkepentingan dalam lapora keuangan. Apabaila auditor memberikan opini wajar namun auditor tidak memberikan bukti bukti yang memadai maka auditor akan mendapatkan masalah menganai standar kinerja yang dilakukan. Tekanan ketaatan yang diterima auditor tidak hanya dilakukan dari pihak klien saja, namun dari pihak atasan (audit senior) juga akan memberikan otaritas kerja yang banyak. Sehingga tekanan ketaatan baik dari klien maupun dari atasan akan berpengaruh terhadap audit judgment (Priatiningsih, 2018).

Pengetahuan aditor berpengaruh signifikan terhadap Audit Judgment, berdasarkan uji hipotesis dengan menggunakan uji regresi logistik diperoleh temuan pengetahuan aditor berpengaruh signifikan terhadap Audit Judgment. Pengetahuan yang dimiliki oleh auditor sangat penting sehingga kinerja yang dilakukan akan lebih efekif. Pengetahuan yang dimiliki auditor akan menambah pengalaman, sehingga pengalaman akan lebih memudahkan auditor untuk mengetahui berbagai masalah yang lebih mendalam (Armanda \& Ubaidillah, 2014).

\section{Simpulan dan Saran}

Simpulan. Hasil dari penelitian ini menunjukkan ukuran perusahaan tidak berpengaruh terhadap audit judgment karena perusahaan yang memiliki total harta yang banyak tidak akan mempengaruhi judgemnt yang dikeluarkan oleh auditor, namun auditor akan memberikan evaluasi dan memberikan saran yang membangun untuk mengembangkan bisnis yang dijalani oleh perusahaan. Tekanan ketaatan akan berpengaruh terhadap audit judgment karena adanya tuntutan dari pihak klien untuk memberikan pendapat kewajaran mengenai laporan keuangan yang diterbitkan oleh perusahaan, sehingga perusahaan dianggap sehat dan selalu berkembang, hal ini akan memberikan citra yang baik bagi perusahaan. Dilema etika yang kedua dalam kinerja audit yaitu mendapat tekanan ketaatan dari pihak atasan, yang akan memunculkan konflik otoritas kerja bagi audit junior juga akan berpengaruh sehingga tekanan akan ketaatan memiliki pengaruh pada audit judgmet. Pengetahuan auditor berpengaruh terhadap audit judgment. Tingkat pengetahuan yang tinggi akan memudahkan auditor untuk menyelesaikan setiap masalah, sehingga auditor akan dapat mendeteksi kesalahan salah saji yang bersikap materiil maupun non meteriil yang telah disajikan oleh perusahaan. Maka pengetahuan auditor ini sangat berpengaruh terhadap pemberian judgment auditor.

Saran. Keterbatasan dalam penelitian ini adalah ada sebagian perusahaan yang tidak mempublikasikan laporan keuangan selama tiga tahun berturut - turut sehingga tidak semua indikator data perusahaan food and beverage yang terdaftar di BEI digunakan sebagai sampel perusahaan. Peneliti lain disarankan menggunakan jenis perusahaan yang beda sebagai penelitian sebagai pembanding maupun perusahaan yang berbeda sektor supaya memperoleh 
data yang lebih banyak, data yang banyak akan memperkuat keakuratan data. Selain menggunakan sampel yang berbeda solusi yang lain bagi peneliti selanjutnya yaitu penambahan periode penelitian karena penelitian tidak hanya terbatas ditahun 2016-2018 saja. Adanya tambahan periode penelitian akan menunjukkan hasil yang lebih aktual.

\section{DAFTAR PUSTAKA}

Ainia, S. \& Prayudiawan, H. (2011). Pengaruh Akuntabilitas, Pengetahuan Audit Dan Gender Terhadap Kualitas Hasil Kerja Auditor Internal (Studi Empiris Pada Inspektorat Wilayah Provinsi Dki Jakarta). 4(1), 155-175.

Arisadi, Y. C., Djumahir. \& Atim, D. (2011). Pengaruh Ukuran Perusahaan, Umur Perusahaan, Current Ratio , Debt to Equity Ratio dan Fixed Asset to Total Asset Ratio terhadap Kinerja Keuangan pada Perusahaan Manufaktur di Bursa Efek Indonesia. Jurnal Aplikasi Manajemen, 3(66), 567-574.

Ariyantini, K. E., Sujana, E., Ari, N., \& Darmawan, S. (2014). Pengaruh Pengalaman Auditor, Tekanan Ketaatan Dan Kompleksitas Tugas Terhadap Audit Judgment ( Studi Empiris Pada Bpkp Perwakilan Provinsi Bali). E-Journal S1 Universitas Pendidikan Ganesha, 2(1), 1-10.

Armanda, R. \& Ubaidillah. (2014). Pengaruh Etika Profesi, Pengetahuan, Pengalaman, Dan Independensi Terhadap Auditor Judgement Pada Badan Pemeriksa Keuangan (BPK) Perwakilan Sumatera Selatan. Jurnal Manaajemen dan Bisnis Sriwijaya, 12(1), 75-89.

Drupadi1, M. J. \& Sudana, I. P. (2015). Pengaruh Keahlian Auditor, Tekanan Ketaatan Dan Independensi Pada Audit Judgment. E-Jurnal Akuntansi Universitas Udayana, 12(3), 623-655.

Fitriani, S. \& Daljono. (2012). Pengaruh Tekanan Ketaatan, Kompleksitas Tugas, Pengetahuan Dan Persepsi Etis Terhadap Audit Judgement. Journal of Accounting, 1(1), $1-12$.

Kencana R, M. (2018). 2018, Industri Makanan dan Minuman Bakal Tumbuh 10 Persen. Retrieved July 23, 2019, from Liputan6 website: https://www.liputan6.com /bisnis/read/3243577/2018-industri-makanan-dan-minuman-bakal-tumbuh-10-

Kusumo, C. Y. \& Ari, D. (2016). Pengaruh Perputaran Modal Kerja, Ukuran Perusahaan, Dan Diversifikasi Terhadap Profitabilitas (Studi Pada Perusahaan Food And Beverage Yang Terdaftar Di Bei Periode 2013 - 2016). Jurnal Administrasi Bisnis, 57(1), 83-89.

Patricia. (2018). Pengaruh Profitabilitas, Likuiditas, dan Ukuran Perusahaan Terhadap Nilai Perusahaan Dengan Kinerja Keuangan Sebagai Variabel Intervening (Studi Empiris Pada Perusahaan Manufaktur Yang Terdaftar Di Bursa Efek Indonesia). Jurnal Manajemen Bisnis, 13(1), 25-42.

Prasetyorini, B. F. (2013). Pengaruh Ukuran Perusahaan, Leverage, Price Earning Ratio Dan Profitabilitas Terhadap Nilai Perusahaan. Jurnal Ilmu Manajemen, 1(1), 183-196.

Priatiningsih, D. (2018). Pengaruh Pengetahuan, Tekanan Ketaatan Dan Kompelsitas Tugas Terhadap Audit Judgment Internal Auditor Pemerintah. Jurnal Ekonomi Dan Bisnis, 2l(1), 12-16.

Putri, F. P. (2015). Pengaruh Pengetahuan Auditor, Pengalaman Auditor, Kompleksitas Tugas, Locus Of Control, Dan Tekanan Ketaatan Terhadap Audit Judgment (Studi Kasus Pada Perwakilan Bpkp Provinsi Riau). Jom FEKOM, 2(2), 1-15.

Refdi1, Kirmizi, \& Restu, A. (2010). Pengaruh Kompetensi, Independensi, Kepatuhan Pada Kode Etik Dan Motivasi Terhadap Kualitas Audit Aparat Inspektorat Se-Propinsi Riau. Jurnal SOROT, 8(2), 120-132.

Saragih, M. R. (2018). Pengaruh Ukuran Perusahaan, Solvabilitas Dan Komite Audit Terhadap Audit Delay. Jurnal Akuntansi Berkelanjutan Indonesia, 1(3), 352-371. 
Sofiani, M. M. \& Tjondro, E. (2014). Pengaruh Tekanan Ketaatan , Pengalaman Audit, Dan Audit Tenure Terhadap Audit Judgement. 4(1), 1-10.

Sukrisno. (2016). Auditing (4th ed.). Jakarta: Salemba Empat.

Tampubolon. (2018). Pengaruh Tekanan Ketaatan, Pengetahuan, Dan Pengalaman Auditor Terhadap Audit Judgment. InFestasi, 14(2), 169-177.

Trisnani, S. (2010). Kompleksitas Tugas, Keahlian Audit Dan Tekanan Ketaatan Pengaruhnya Terhadap Audit Judgment. Jurnal Strategi Akuntansi, 2(2), 105-130. 